\title{
Hubungan antara Malondialdehyde [MDA] dengan Hasil Luaran Sepsis Neonatorum
}

\author{
Kamilah Budhi Rahardjani \\ Bagian Ilmu Kesehatan Anak, Fakultas Kedokteran Universitas Diponegoro, RSUP Dr. Kariadi Semarang
}

Latar belakang. Sepsis merupakan penyebab morbiditas dan mortalitas terbanyak pada neonatus. Pada sepsis terjadi peningkatan stres oksidatif yang menyebabkan kerusakan jaringan dan hemolisis. Kadar MDA serum merupakan biomarker adanya stress oksidatif.

Tujuan. Mengetahui hubungan antara MDA serum dengan hasil luaran sepsis pada neonatus.

Metode. Penelitian observasional prospektif dilakukan pada neonatus sepsis yang dirawat di PBRT (Peawatan Bangsal Risiko Tinggi) RSUP Dr. Kariadi Semarang, Oktober 2007 sampai dengan Januari 2008. Diagnosis sepsis berdasar gejala klinik dan pemeriksaan laboratorium. Keluaran sepsis dikelompokkan menjadi dua yaitu perburukan (BR) dan perbaikan (BI). Kadar MDA serum diukur dua kali saat terdiagnosis sepsis (MDA1) dan pada hari ke-5 atau bila terjadi disfungsi organ / meninggal / perburukan (MDA2) dengan menggunakan metode spektofotometri. Analisis statistik menggunakan Uji Wilcoxon Signed-Rank, MannWhitney, ROC analysis dan Fisher-exact.

Hasil. Subjek penelitian terdiri dari 41 neonatus sepsis, 33 neonatus BI dan 8 neonatus BR. Rerata kadar MDA1 2,97 $\pm 0,14$ dan MDA2 3,05 $\pm 0,34$. Kadar MDA 1 kelompok BI 2,95 $\pm 0,117$, kelompok BR 3,08 $\pm 0,172$ $(\mathrm{p}=0,03)$. Kadar MDA2 kelompok BI 2,97 $\pm 0,182$, kelompok BR 3,38 $\pm 0,591$ ( $\mathrm{p}=0,006)$. Kelompok BI MDA2 meningkat tak bermakna ( $\mathrm{p}=0,9)$, kelompok BR, MDA2 meningkat bermakna ( $\mathrm{p}=0,01)$. Kurva ROC luas area bawah kurva MDA1 0,75 (p=0,03), cut-off-point=2,928 ng/mL. Dijumpai hubungan bermakna antara kategori MDA1 dengan luaran sepsis $(\mathrm{p}=0,02)$. Risiko relatif MDA1 22,928 ng/mL untuk hasil luaran sepsis perburukan 7,4 X (95\% CI=1,4-37,2).

Kesimpulan. Terdapat hubungan antara kadar MDA serum dengan hasil luaran sepsis neonatorum. (Sari Pediatri 2010;12(2):82-7).

Kata kunci: neonatus, sepsis, MDA

\footnotetext{
Alamat korespondensi:

Dr. Kamilah Budi Rahardjani, SpA(K). Bagian IKA FK-UNDIP/RS Dr. Kariadi Semarang Jawa Tengah. Telp. 024 - 8414296, Fax. 024 - 8318617.
}

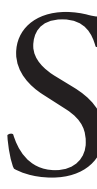

epsis terjadi apabila bakteri yang masuk ke dalam tubuh atau sirkulasi darah tidak dapat dieliminasi efektif oleh tubuh atau terjadi kegagalan mekanisme pertahanan. ${ }^{1,2}$ Hal tersebut akan merangsang respon inflamasi sistemik (Systemic Inflammatory Response Syndromel SIRS). Sepsis dapat berkembang menjadi berat (severe sepsis), dan berakhir dengan kematian. ${ }^{3,4}$ Menurut 
American College of Chest Physicians (ACCP) dan the American Society of Critical Care Medicine (SCCM) sepsis adalah SIRS yang disebabkan oleh infeksi baik suspected/tersangka maupun proven/terbukti infeksi. ${ }^{5}$ Sepsis berat adalah sepsis disertai disfungsi organ kardiovaskular atau gangguan nafas akut atau adanya gangguan fungsi dua organ lain. ${ }^{3}$

Angka kejadian neonatus sepsis di negara maju (1-5/1000 kelahiran hidup), di negara berkembang masih cukup tinggi (1,8-18/1000 kelahiran hidup) dan merupakan penyebab kematian neonatus utama (42\%). ${ }^{6}$ Di Indonesia, Survei Kesehatan Rumah Tangga (SKRT) tahun 2002, angka kelahiran bayi diperkirakan mencapai 4,6 juta jiwa per tahun dengan angka kematian bayi (infant mortality rate) 48/1000 kelahiran hidup. ${ }^{7}$ Di RSUP Dr. Kariadi Semarang angka kejadian infeksi pada neonatus tahun 2004 $33,1 \%$, dengan kematian 20,3\%. ${ }^{8}$ Sedangkan di RS Cipto Mangunkusumo Jakarta tahun 2005 infeksi pada neonatus terjadi pada $13,68 \%$ dari seluruh kelahiran dengan angka kematian $14,18 \% .^{9}$

Pelepasan sitokin proinflamasi maupun antiinflamasi oleh makrofag pada sepsis, menyebabkan lepasnya berbagai mediator sekunder seperti mediator vasoaktif dan spesies oksigen reaktif (SOR) mengawali proses imunoinflamasi. ${ }^{10,11}$ Mediator SOR merupakan oksidan kuat akibat reduksi satu elektron oksigen, apabila SOR yang dihasilkan lebih besar dibanding dengan yang dapat diredam oleh mekanisme pertahanan sel (anti oksidan) terjadi stres oksidatif. ${ }^{12}$ Kehadiran SOR pada infeksi menimbulkan kerusakan oksidatif berupa lisis membran sel, maupun jaringan tubuh yang mengandung lipid. ${ }^{13}$ Peroksidasi lipid mengakibatkan kerusakan struktur molekul penyusun membran berakibat lisis sel pada umumnya maupun sel eritrosit atau hemolisis. ${ }^{2,14}$ Peristiwa ini mengakibatkan dilepaskannya malondialdehyde (MDA) yang selanjutnya senyawa ini dapat menyebabkan kerusakan sel. ${ }^{14}$

Melakukan prediksi terhadap luaran sepsis merupakan hal yang perlu dilakukan untuk menurunkan morbiditas dan mortalitas neonatus. Mediator MDA merupakan suatu produk akhir peroksidasi lipid, digunakan sebagai biomarker biologis peroksidasi lipid dan dapat menggambarkan derajat stres oksidatif. ${ }^{15}$ Pada neonatus sepsis terjadi peningkatan stress oksidatif maka terdapat peningkatan MDA. ${ }^{10,15}$ Berdasarkan uraian tersebut, MDA sebagai penanda adanya kerusakan jaringan akibat stress oksidatif kemungkinan dapat dipergunakan sebagai penanda prognosis sepsis pada neonatus.

\section{Metode}

Dilakukan penelitian observasional analitik prospektif yang bertujuan untuk mengetahui hubungan antara MDA serum dengan hasil luaran sepsis pada neonatus. Subyek penelitian adalah 41 neonatus sepsis (suspect maupun proven) yang dirawat di Bangsal Perawatan Bayi Risiko Tinggi (PBRT) RSUP Dr Kariadi Semarang, pada Oktober 2007 sampai dengan akhir Januari 2008. Neonatus dengan kelainan kongenital berat, mendapat transfusi darah, inkompatibilitas golongan darah, sepsis berat pada saat awal perawatan, menolak diikutsertakan, tidak diikutsertakan dalam penelitian. Besar sampel dihitung dengan menggunakan rumus luas area di bawah kurva $\mathrm{ROC}^{16}$ dan pengambilan sampel dilakukan dengan metode consecutive sampling. Pemeriksaan spesimen darah dilakukan di Laboratorium Biotek Universitas Gajah Mada Yogyakarta

Diagnosis infeksi ditentukan berdasar gejala klinis, pemeriksaan laboratorium darah dan biakan darah. Gejala klinis ditetapkan dengan sistem skor Gejala Klinis Sepsis Monintja, ${ }^{17}$ kelainan laboratorium ditetapkan dengan Sistem Skor Hematologis. ${ }^{18}$ Sampel biakan darah diperiksa sebelum pemberian antibiotik. Biakan darah menggunakan tabung BD Bactec 40 cc, (BD Company, USA). Pemeriksaan kadar MDA serum dilakukan dua kali yaitu saat diagnosis sepsis ditegakkan (MDA1) dan pada hari ke-5 perawatan atau sebelumnya bila telah terjadi gagal organ (MDA2). Mediator MDA diperiksa menggunakan metode Hunter. ${ }^{19}$

Sepsis disebut perbaikan apabila gejala klinis dan pemeriksaan laboratorium membaik. Perburukan bila gejala klinis dan pemeriksaan laboratorium memburuk/sepsis berat atau meninggal, yang dievaluasi pada hari ke-5 perawatan atau kurang dari lima hari apabila terdapat tanda gagal organ. Protokol penelitian telah mendapat persetujuan dari Komisi Etik Penelitian Kesehatan FK UNDIP RSDK dan seluruh orang tua pasien/wali telah dimita persetujuanya dengan informed consent tertulis.

Analisis Receiver Operating Characteristics (ROC) dilakukan untuk mengetahui apakah kadar MDA serum dapat dipergunakan sebagai indikator prognosis sepsis pada neonatus. Hubungan antara MDA dengan hasil luaran sepsis neonatus dianalisis dengan uji $\chi 2$. Risiko MDA untuk luaran perburukan dinyatakan sebagai risiko relatif, dan nilai $\mathrm{p}<0,05$ dianggap bermakna. Analisis statistik dilakukan dengan menggunakan SPSS 13. 


\section{Hasil}

Jumlah subyek yang diteliti 41 neonatus sepsis, terdiri dari 33 neonatus perbaikan (BI) dan 8 neonatus perburukan (BR). Karakteristik subyek tertera pada Tabel 1.

Pada saat masuk perawatan, seluruh neonatus tidak ada yang menderita disfungsi organ. Sampai hari ke- 5 perawatan dijumpai $8(19,5 \%)$ neonatus kelompok BR dan $33(80,5 \%)$ neonatus kelompok BI.

Tabel 2 menunjukkan kadar MDA1 kelompok $\mathrm{BR}$, lebih tinggi bermakna dibanding kelompok BI $(\mathrm{p}=0,03)$. Demikian juga kadar MDA2 kelompok BR lebih tinggi bermakna dibanding kelompok BI $(\mathrm{p}=0,01)$.

Gambar 1 menunjukkan bahwa pada kelompok BI tidak terdapat perbedaan antara kadar MDA1 dengan MDA2 ( $\mathrm{p}=0,9)$, sedangkan pada kelompok $\mathrm{BR}$, dijumpai perbedaan yang bermakna $(\mathrm{p}=0,01)$. Berdasarkan hasil tersebut, diketahui bahwa pada

Tabel 1. Karakteristik subyek

\begin{tabular}{lc}
\hline Variabel $\mathrm{n}(\%)$ & \\
\hline Jenis kelamin & \\
$\quad$ Laki-laki & $24(58,5)$ \\
Perempuan & $17(41,5)$ \\
$\quad$ Rerata umur saat dirawat (hari) & $1,4(\mathrm{SD}=0,89)$ \\
Berat badan lahir (gram) & \\
$\quad<2500$ & $2(4,9)$ \\
$2500-4000$ & $39(95,1)$ \\
Cara lahir & \\
$\quad$ Spontan & $14(34,1)$ \\
Sectio caesarea & $17(41,5)$ \\
$\quad$ Versi ekstraksi & $10(24,4)$ \\
Usia gestasi & \\
Preterm & $6(14,6)$ \\
Aterm & $33(80,5)$ \\
Post term & $2(4,9)$ \\
\hline
\end{tabular}

Tabel 2. Hubungan antara kadar MDA dengan luaran sepsis

\begin{tabular}{|c|c|c|c|}
\hline \multirow[b]{2}{*}{ Variabel } & \multicolumn{2}{|c|}{ Luaran sepsis } & \multirow[b]{2}{*}{$\mathrm{p}^{*}$} \\
\hline & $\begin{array}{c}\text { Perbaikan } \\
\text { Median (25\%-75\%) }\end{array}$ & $\begin{array}{c}\text { Perburukan } \\
\text { Median (25\%-75\%) }\end{array}$ & \\
\hline MDA & $2,91(2,67-3,09)$ & $3,06(2,89-3,17)$ & 0,03 \\
\hline MDA 2 & $2,93(2,89-3,16)$ & $3,10(3,00-3,82)$ & 0,0006 \\
\hline
\end{tabular}

*Uji Mann-Whitney

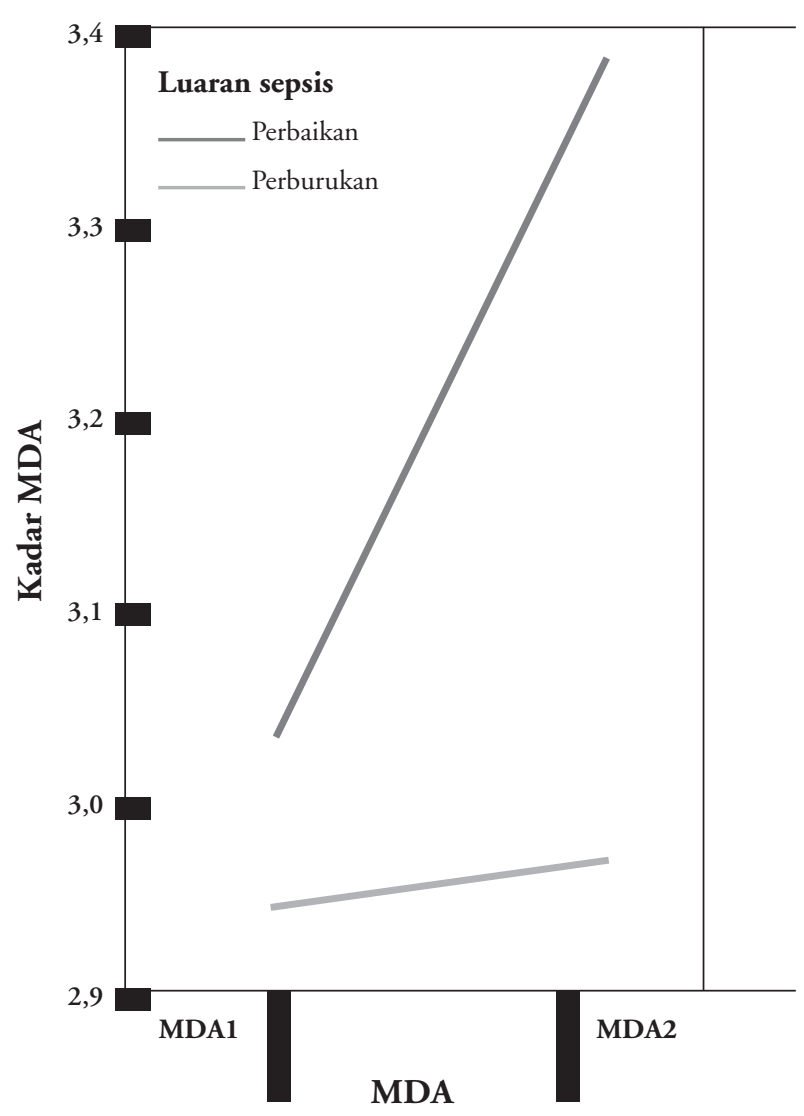

Gambar 1. Peningkatan kadar MDA berdasarkan luaran sepsis

kelompok BR terjadi peningkatan bermakna antara kadar MDA1 dan MDA2

Gambar 2 menunjukkan bahwa luas area di bawah kurva ROC kadar MDA1 adalah 0,75 (95\% $\mathrm{CI}=0,59$ - 0,92; $\mathrm{p}=0,03)$, menunjukkan kadar MDA1 dapat digunakan sebagai indikator prognosis keluaran sepsis. Nilai cut-off-point kadar MDA1 adalah 2,928 $\mathrm{ng} / \mathrm{mL}$.

Tabel 3 menunjukkan hubungan yang bermakna antara MDA 1 dengan hasil luaran sepsis $(\mathrm{p}=0,02)$. Risiko relatif (RR) untuk terjadinya perburukan pada sepsis dengan kadar MDA1 $\geq 2,928 \mathrm{ng} / \mathrm{mL}$ adalah 7,4 kali. Temuan tersebut menunjukkan pasien dengan kadar MDA1 $\geq 2,928 \mathrm{ng} / \mathrm{mL}$ mempunyai kemungkinan 7,4 kali lebih besar untuk mengalami perburukan klinis. Berdasarkan hasil luaran sepsis sebagai baku emas diperoleh nilai sensitivitas 87,5 $\%$, menunjukkan MDA 1 dapat memprediksi 
luaran sepsis perburukan $87,5 \%$. Nilai spesifisitas 60,6\%, berarti MDA 1 hanya dapat memprediksi sepsis membaik $60,6 \%$. Nilai duga positif rendah $35,0 \%$ sedangkan nilai duga negatif $95,2 \%$. Temuan tersebut berarti apabila MDA $1 \geq 2,928 \mathrm{ng} / \mathrm{mL}$ hanya $35 \%$ pasien yang benar-benar akan mengalami perburukan, sebaliknya apabila hasil MDA $1<2,928$ $\mathrm{ng} / \mathrm{mL}$ maka $95,2 \%$ pasien benar-benar mengalami perbaikan. Berdasarkan hasil penelitian, ditemukan bahwa kadar MDA1 memiliki sensitivitas tinggi tetapi tidak spesifik sebagai indikator untuk memprediksi keluaran sepsis.

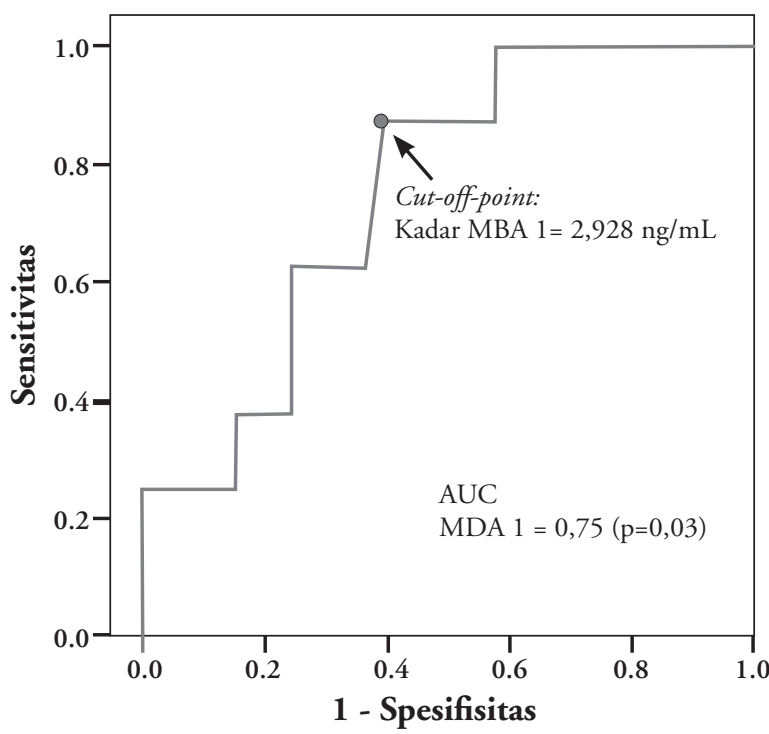

Gambar 2. Kurva ROC kadar MDA 1 sebagai indikator prognosis sepsis neonatorum

Tabel 3. Hubungan antara kategori MDA 1 dengan hasil luaran sepsis

\begin{tabular}{cccc}
\hline $\begin{array}{c}\text { Kategori MDA 1 } \\
(\text { ng/mL) }\end{array}$ & $\begin{array}{c}\text { Keluaran sepsis } \\
\text { Perburukan } \\
\text { (n) }\end{array}$ & $\begin{array}{c}\text { Perbaikan } \\
\text { (n) }\end{array}$ & \\
\hline$\geq 2,928$ & 7 & 13 & 20 \\
$<2,928$ & 1 & 20 & 21 \\
& 8 & 33 & 41 \\
\hline
\end{tabular}

Uji Fisher-exact

Risiko relatif $=7,4$ (95\% CI=1,4-37,2\%)

Sensitivitas $=87,5 \%(95 \% \mathrm{CI}=64,6-100 \%)$

Spesifisitas $=60,6 \%(95 \% \mathrm{CI}=43,9-77,3 \%)$

Nilai duga positif $=35,0 \% \quad(95 \% \mathrm{CI}=14,1-55,9 \%)$

Nilai duga negatif $=95,2 \%(95 \% \mathrm{CI}=86,1-100 \%)$

\section{Pembahasan}

Dalam proses metabolisme normal eritrosit maupun sel tubuh lainnya, berbagai rangsangan menghasilkan spesies oksigen reaktif (SOR) secara terus menerus dalam jumlah besar. Apabila terjadi ketidakseimbangan antara produksi oksidan dan antioksidan dalam tubuh, maka akan terjadi stres oksidatif. Mediator MDA suatu senyawa sangat reaktif, merupakan produk akhir dari peroksidasi lipid, yang biasa digunakan untuk menilai stres oksidatif. ${ }^{20,21}$

Kapoor $^{22}$ pada penelitiannya melaporkan peningkatan kadar MDA pada sepsis, dan menyatakan bahwa kadar MDA pada sepsis lebih tinggi bermakna dibanding neonatus tanpa sepsis. Batra ${ }^{23}$ juga melaporkan peningkatan kadar MDA pada sepsis, didapati kadar MDA pada kelompok BR meningkat bermakna dibanding pada kelompok BI. Kapoor ${ }^{22}$ melaporkan bahwa pada sepsis neonatorum yang disertai disfungsi organ dijumpai perubahan bermakna kadar MDA.

Kadar MDA yang tinggi pada kelompok BR terjadi sebagai respon terhadap infeksi berat. Pada saat infeksi/sepsis, terjadi perubahan fisiologi sistem imun humoral maupun selular dalam upaya mengimbangi atau mengeliminasi mikroba melalui pembentukan komplemen, antibodi dan pengeluaran mediator inflamasi. ${ }^{3,4}$ Respon inflamasi sistemik terhadap bakteri, virus dan jamur adalah sama di antaranya terbentuknya SOR. ${ }^{3}$ Ketidak seimbangan antara sitokin proinflamasi dan antiinflamasi mengakibatkan peningkatan SOR dan peningkatan kadar MDA. ${ }^{10}$

Produksi SOR yang berlebihan pada infeksi bakteri mempunyai potensi untuk menimbulkan kerusakan oksidatif pada eritrosit sehingga mengakibatkan hemolisis ${ }^{13}$ Penggunaan antibiotik tertentu sebagai terapi sepsis dapat menyebabkan hemolisis ${ }^{20}$ Beberapa jenis bakteri tertentu mensekresi hemolisin yang dapat mengakibatkan hemolisis. Aktivasi komplemen C5-C9 menyebabkan terjadi cedera membran berupa lisis eritrosit, kebocoran membran plasma sel berinti dan lisis bakteri gram negatif akibat terbentuk kompleks membran litik. ${ }^{24}$ Peningkatan hemolisis dan cedera sel pada umumnya akan meningkatkan kadar MDA. ${ }^{25}$

Nielsen $\mathrm{dkk}^{25}$ menjelaskan terjadi penurunan antioksidan pada syok septik dan peningkatan kadar thiobarbituric acid related substance (TBARS) plasma pada disfungsi dua organ atau lebih; mengindikasikan terjadinya peroksidasi lipid. Faktor lain yang turut 
berpengaruh terhadap keluaran sepsis adalah kecepatan dan ketepatan penegakan diagnosis, tata laksana pasien yang baik suportif maupun kausatif. Selain itu beberapa faktor risiko keluaran sepsis turut mempengaruhi, misal berat lahir rendah, maturitas bayi, dan penyakit penyerta.

Berdasarkan teori dan hasil penelitian kami, dapat disimpulkan bahwa semakin berat derajat sepsis akan semakin banyak dilepaskan oksidan dan menurunnya antioksidan berakibat peningkatan stres oksidatif dan peningkatan MDA. Sepsis dengan kadar MDA tinggi menunjukkan adanya kerusakan jaringan yang lebih parah. Ditemukan MDA dapat menyebabkan kerusakan jaringan sehingga kadar MDA yang tinggi juga turut berperan dalam memperberat kerusakan jaringan. Walaupun demikian hasil penelitian kami menunjukkan bahwa kadar MDA pada saat diagnosis sepsis ditegakkan cukup sensitif namun tidak spesifik untuk memprediksi keluaran sepsis neonatorum. Diduga karena pemeriksaan TBARS dengan metode spektrofotometri memiliki beberapa kelemahan yaitu beberapa senyawa aldehid selain MDA juga dapat bereaksi dengan TBARS dan pada pemeriksaan spektrofotometri ikut terukur pula absorbansi yang sama dengan MDA. Selain itu MDA bukan produk yang spesifik pada proses peroksidasi lipid sehingga dapat menimbulkan positif palsu yang berakibat nilai duga positif yang rendah. Metode pemeriksaan lain yaitu High Performance Liqiud Chromatography (HPLC) dilaporkan dapat meningkatkan spesifisitas pada pemeriksaan kadar MDA. ${ }^{26}$ Maka perlu dilakukan penelitian lanjutan bersifat multisenter dengan menggunakan metode HPLC.

Disimpulkan bahwa terdapat hubungan antara kadar MDA serum dengan hasil luaran sepsis neonatorum.

\section{Daftar Pustaka}

1. Jain N, Jain VB. Neonatal sepsis. Dalam: The neonate. a practical manual of common newborn problems. New Delhi: Aditya Med Publ; 2003.h.80-4.

2. Stoll BJ. Infections of neonatal infant. Dalam: Behrman RF, Kleigman RM, Jenson HB. penyunting. Nelson Textbook of Pediatrics. Edisi ke-17 Philadelphia: WB Saunders Co; 2004.h.623-40.

3. Short MA. Linking the sepsis triad of inflammation, coagulation, and suppressed fibrinolysis to infants. Adv
Neonatal Care 2004; 5: 258-73.

4. Shulman ST. Pengenalan penyakit infeksi. Dalam: Dasar klinis dan biologis penyakit infeksi edisi IV (terjemahan). Gajah Mada University Press; 1994.h.1-5.

5. Latief A. Pendekatan diagnosis sepsis. Dalam: Prosiding Simposium Nasional PGD VI: Pendekatan mutakhir tata laksana sepsis pediatrik; Medan: 2003. h.28-35.

6. Gerdes JS. Diagnosis and management of bacterial infections in the neonate. Pediatr Clin North Amer 2004;51: 939-59.

7. Departemen Kesehatan \& Kesejahteraan Sosial RI. Sensus Kesehatan Rumah Tangga (SKRT). 2002.

8. Anonymous. Protap Pelayanan Perinatologi RSDK. Unpublished.

9. Rohsiswatmo R. Kontroversi diagnosis sepsis neonatorum. Dalam: Update in neonatal infection. Pendidikan Kedokteran Berkelanjutan IKA XLVIII. Jakarta; 2005.h.32-4.

10. Paterson, RL, Webster NR. Sepsis and inflammatory response syndrome. J Royal Coll Surg Edinburgh 2002; 45:178-82.

11. Marshall, John C, Taneja R. Terminology and conceptual challenges, Dalam: Sepsis and multiple organ dysfunction. a multidisciplinary approach. Philadelphia:WB Saunders Company; 2000.h.12-8.

12. Langseth L. Oxidants and antioxidants: some basic concepts. Dalam: Bracco U, Jardine NJ, penyunting. Oxidants, antioxidants, and disease prevention. Belgium: International Life Science Institute; 1994.h.1-4.

13. Oski FA, Naiman JL. Disorder of red cell metabolism. Dalam: Hematologic problems in the Newborn. Edisi-2. Philadelphia: WB Saunders Co; 1972.h. 83-132.

14. Droge W. Free radicals in the physiology control of cell function. Physiol Rev 2003; 82: 47-95.

15. Yigit S, Yurdakok M, Kilinc K, Oran O, Erdem G, Tekinalp G. Serum malondialdehyde concentration as a measure of oxygen free radical damage in preterm infants. J Turk J Pediatr 1998;40:177-83.

16. Pepe MS. The statistical evaluation of medical tests for classification and prediction. New York: Oxford University Press; 2003.h.225-7.

17. Monintja HE. Infeksi sistemik pada neonatus. Dalam: Yu VYH, Monintja HE, penyunting. Beberapa masalah perawatan intensif neonatus. Jakarta: Balai Penerbit FKUI; 1997.h.545-9.

18. Sales-santos M, Bunye MO. The complete blood count and hematologic finding as screening criteria for neonatal sepsis. Proceedings of Makati Medical Center;199:4050. 
19. Yagi K. Assay for blood plasma or serum. Methods Enzymol 1984;105:328-31.

20. Halliwell B. Reactive oxygen species in living systems: source, biochemistry and role in human disease. Am J Med 1991; 91 (suppl 30) : 14S-21S.

21. De Zwart LL, Meerman JHN, Commandeur JNM, Vermulen NPE. Biomarker of free radical damage. Application in experimental animals and humans. Free Rad Biol Med 1998; 26: 202-26.

22. Kapoor K, Basu S, Das BK, Bhatia BD. Lipid peroxidation and antioxidants in neonatal septicemia. J Trop Ped 2006 52:372-5.

23. Batra S, Kumar R, Seema, Kapoor AK, Ray G. Alterations in antioxidant status during neonatal sepsis.
Ann Trop Paed 2000; 20: 27-33.

24. Benjamini E, Coico R, Sunshine G. Hipersentivity reaction:Antibody-mediated (Type II) Cytotxic reactions and Immun complex (Type III) reactions. Dalam: Benjamini E, Coico R, Sunshine G, penyunting. Immunology, a short course. Edisi ke-4. New York: Aj Wiley and Sons; 2000.h.301-11.

25. Nielsen F, Mikkelsen BB, Nielsen JB, Andersen HR, Grandjean P. Plasma malondialdehyde as biomarker oxidative stress reference interval and effects of life style factors. Clin Chem 1997; 43:1209-14.

26. Dalle-Donne I, Rossi R, Colombo R,Giustarini D, Milzani A. Biomarkers of oxidative damage in human disease. Clin Chem 2006;52:601-23. 